\title{
Anatomy of a Serial Killer: Differential Diagnosis of Tuberculosis Based on Rib Lesions of Adult Individuals From the Coimbra Identified Skeletal Collection, Portugal
}

\author{
Ana Luísa Santos ${ }^{1 \star}$ and Charlotte Ann Roberts ${ }^{2}$ \\ ${ }^{1}$ Departamento de Antropologia, Universidade de Coimbra, 3000-056 Coimbra, Portugal \\ ${ }^{2}$ Department of Archaeology, University of Durham, Durham DH1 3LE, UK
}

\section{KEY WORDS Tib periostitis; pulmonary tuberculosis; Portugal; 20th century}

\begin{abstract}
The role of new bone formation on visceral surfaces of ribs in the diagnosis of tuberculosis (TB) in past human populations has been explored by many researchers, using both skeletal remains with known causes of death and archaeological samples. This study focuses, firstly, on adult skeletons from the Coimbra Identified Skeletal Collection in Portugal and investigates the skeletal manifestations of individuals known to have died from TB; secondly, this study focuses on the role of rib lesions in the diagnostic criteria for TB. One hundred and fifty-seven males and 106 females aged between 22-87 years were examined; causes of death were assigned as pulmonary TB, extrapulmonary TB, and pulmonary non-TB; a control group, extrapulmonary non-TB, was selected from the remaining individuals. Of
\end{abstract}

Tuberculosis (TB) is an infectious contagious disease caused by a bacterium from the Mycobacterium tuberculosis complex that affects a variety of domestic and wild animals (Daniel et al., 1994; Vincent and Perez, 1999). In humans, tuberculosis may be a chronic or acute infection of bone and/or soft tissues (Aufderheide and RodríguezMartín, 1998). For this reason, it was classified under many different names in the past, reflecting specific anatomical localizations and lesions, each considered a different disease (French, 1993; Magyar, 1999).

The ancient evidence for tuberculosis in humans dates from the Neolithic (ca. 4000 BC). Some evidence is controversial (Sager et al., 1972; El-Najjar et al., 1997), while some is more convincing (Formicola et al., 1987; Canci et al., 1996). From 4000 BC to recent times, many skeletal findings were described globally (Roberts and Buikstra, 2003). The majority of these data rely on the diagnosis of the spinal changes of tuberculosis, followed by changes in the hip and knee joints (Aufderheide and Rodríguez-Martín, 1998). However, in the periods following prehistory, in a global context, pulmonary TB became more common, being responsible for the majority of deaths from TB, while bone TB, in particular Pott's disease of the spine, was less common. For example, in the Coimbra Cemetery, Cemitério Municipal da Conchada (CMC), records show that pulmonary TB was responsible for 70\% of deaths caused by TB from 1910-1914 (Barata, 2000). However, positive identification of the existence of pulmonary TB in human skeletons is rare, even though it is assumed that most people in the past probably individuals with rib lesions, 85.7\% (69/81) had pulmonary or extrapulmonary $\mathrm{TB}$ as an assigned cause of death, while $17.8 \%$ (16/90) of individuals with rib lesions had a non-TB cause of death. Rib lesions were significantly more common in individuals who had died from TB, although the lesions cannot be considered pathognomonic for TB. In individuals dying from pulmonary TB, ribs in the central part of the rib cage were most affected, at their vertebral ends. The lower part of the rib cage may be a marker for peritoneal TB, and "corallike" new bone formation on ribs may be an indicator of neoplastic disease. Further work on rib involvement in $\mathrm{TB}$ in clinical contexts, and the study of further documented skeletal collections, are recommended. Am J Phys Anthropol 130:38-49, 2006. ๑ 2005 Wiley-Liss, Inc.

acquired TB via the pulmonary route (Vale, 1936). This fact could be responsible for the sharp contrast between the impression of widespread pulmonary tuberculosis in the past seen in historical documents, and the low prevalence of skeletal evidence in both archaeological and recent cases. There are many reasons for this apparent discrepancy. Today, when diagnosing pulmonary TB, physicians generally use chest radiographs and sputum analysis, and do not commonly consider bone change in their diagnosis. However, Guttentag and Salwen (1999, p. 1138) inferred that chronic infections, namely tuberculosis, "may first manifest as periosteal reaction" on the ribs. Another problem is the unfamiliarity of physicians today with many of the preantibiotic manifestations of infectious disease; therefore, important osseous signs may not be described in modern clinical medical texts

Grant sponsor: PRODEP Doctoral Program; Grant number: 5.2, $1 / 96$.

*Correspondence to: Ana Luísa Santos, Departamento de Antropologia, Universidade de Coimbra, 3000-056 Coimbra, Portugal.

E-mail: alsantos@antrop.uc.pt

Received 4 April 2004; accepted 28 July 2004

DOI 10.1002/ajpa.20160

Published online 13 December 2005 in Wiley InterScience (www.interscience.wiley.com). 
(Santos, 2000). Although many individuals may die before skeletal modifications can take place (Wood et al., 1992), bony lesions which do appear may be misinterpreted because bone has a limited response, and careful differential diagnosis is required for confident identification of a specific disease.

Clinical diagnostic criteria used by paleopathologists to identify TB rely on Pott's disease of the spine, a region of the human skeleton with often a good survival rate in archaeologically derived materials (Waldron, 1987). However, in the 1990s, several studies suggested TB as a possible diagnosis for new bone formation on the visceral surfaces of ribs. Evidence was reported from Austria (Wiltschke-Schrotta and Berner, 1999), Canada (Pfeiffer, 1991), Chile (Souza, 2002), Denmark (Weiss and MøllerChristensen, 1971; Bennike, 1999), Egypt (Baker, 1999), Hungary (Molnár and Marcsik, 2003), Lithuania (Jankauskas, 1999), Portugal (Santos and Cunha, 1997; Lopes et al., 1999; Marques, 2000), UK (Chundun, 1991; Boylston, 1991; Goggel, 1992; Murphy, 1994; Roberts, 1999, 2003; Mays et al., 2002; Roberts and Cox, 2003), and the US (Powell, 1988, 1991; Molto, 1990; Stodder, 1990, 1996; Regan et al., 1993; Kelley et al., 1994; Garten, 1997; Lambert, 2002). Additionally, from New England, an 18th/ 19th century individual with new bone formation on the ribs was reported to have been intentionally disturbed as a cultural practice to avoid vampires (believed to be people with tuberculosis) rising from the dead (Sledzik and Bellantoni, 1994).

Studies of relatively "modern" skeletons with documented causes of death have helped to clarify the role of rib lesions in the diagnosis of pulmonary TB. In the $1980 \mathrm{~s}$, research on the Hamann-Todd Collection, curated in the Cleveland Museum of Natural History (Cleveland, $\mathrm{OH}$ ), revealed that new bone formation on ribs was more frequent in tuberculous individuals (Kelley and El-Najjar, 1980; El-Najjar, 1981; Kelley and Micozzi, 1984); 31 of 352 pulmonary TB cases $(8.8 \%)$ had lesions on the visceral surfaces of their ribs (Kelley and Micozzi, 1984). In the Terry Collection, curated by the National Museum of Natural History (Smithsonian Institution, Washington, DC), a stronger connection was found between pulmonary TB and rib lesions. Roberts et al. (1994) analyzed 255 individuals with pulmonary TB as cause of death; rib lesions were found in 157 individuals (61.6\%). More recently, a study was conducted on the Coimbra Identified Skeletal Collection (CISC), curated by the Anthropological Museum at the University of Coimbra. This investigation showed that of 66 juveniles in the collection, new bone formation on the ribs was present in $90.9 \%$ (10 out of 11 ) of those who had died from pulmonary TB (Santos and Roberts, 2001).

From the discussion above, it is clear that more research on this subject is needed. An accurate diagnosis of TB depends on knowledge of the characteristic distribution pattern of associated lesions and their frequency in the skeleton. However, many of the criteria considered in TB diagnosis in paleopathology were developed from the study of skeletons with unknown or uncertain recorded causes of death. Thus, the current study aims to contribute to improving our knowledge and diagnostic criteria for TB in past human populations. This will be achieved by recording the skeletal manifestations of TB in CISC adults in order to reconsider the diagnostic criteria for pulmonary tuberculosis and, by examining differential diagnoses, the role of nontuberculous pulmonary disease in new bone formation on ribs.

\section{MATERIALS AND METHODS}

The Coimbra Identified Skeletal Collection, curated in the Anthropological Museum at the University of Coimbra, is a reliable sample for the study of differential diagnoses of rib lesions. This sample of 505 skeletons was collected in the first half of the 20th century (Rocha, 1995), and all were exhumed from the CMC (Santos, 2000). These individuals died between 1904-1936, i.e., between Koch's identification of the pathogen for TB in 1882 (Brock, 1982) and the introduction of antibiotic therapy in the late 1940s (Earnest and Sbarbaro, 1993; Almeida, 1995; Porter, 1996; Cule, 1999). Research on documents from several institutions and in medical literature from the beginning of the 20th century indicates that the cause-of-death records associated with the CISC are accurate and reliable (Santos, 2000). For each individual, a record exists which provides cause of death and other medical and personal information. Nearly all the skeletons are complete and well-preserved, although some have destruction. The sample examined consisted of 263 adult individuals (157 males and 106 females), with ages ranging from $22-87$ years. This sample comprised all adult individuals in the CISC with TB and pulmonary nontuberculosis as a cause of death, and a control group was selected randomly from remaining individuals. The skeletons of individuals were observed macroscopically without prior knowledge of cause of death. Some bones were also radiographed, using the facilities of the Coimbra University Hospital (CUH). Firstly, the ribs of each individual were sequenced by side and number according to Mann (1993). Because periosteal reaction can be very subtle in appearance and visibility, a lamp was always positioned a few centimeters from the bone surface under observation. To note the precise location of new bone formation, three regions were considered for each rib: vertebral end, medial shaft, and sternal end. The presence or absence of new bone formation was assigned to each rib according to side and number of the rib affected, and by region on the rib. All data were analyzed using SPSS and Actus, allowing the application of chi-square tests of significance.

\section{RESULTS Frequency of rib involvement}

From the 263 adults observed, 92 (35.0\%) individuals were excluded from analysis. Five individuals did not have ribs (skeletons (sk.) 76, 77, 78, 79, and 486), for one individual (sk. 421) the skeleton did not match the autopsy description, one individual (sk.11) had pathological lesions on his ribs that prevented observations, and the remaining 85 had postmortem damage precluding an accurate observation. The ribs of the remaining 171 individuals observed were divided into four main groups related to their cause of death: pulmonary tuberculosis, extrapulmonary tuberculosis (e.g., TB in the left kidney), pulmonary nontuberculosis (e.g., chronic bronchitis, pneumonia), and extrapulmonary nontuberculosis (e.g., tumors) (Table 1).

Periosteal reaction on the visceral surface of the ribs was present in $49.7 \%$ (85/171) of observable individuals. Of individuals who died from pulmonary tuberculosis, $85.7 \%$ (54/63) were affected, while for those dying from nontuberculous causes, only $17.8 \%$ (16/90) of individuals were affected. Four out of 26 individuals (15.4\%) were affected with a pulmonary non-TB cause of death, and 
TABLE 1. Presence of periostitis on ribs by disease

\begin{tabular}{lrrc}
\hline \multirow{2}{*}{$\quad$ Group of diseases } & \multicolumn{3}{c}{ Ribs } \\
\cline { 2 - 4 } & $\mathrm{N}$ & $\mathrm{n}$ & $\%$ \\
\hline 1. Pulmonary TB & 63 & 54 & 85.7 \\
2. Extrapulomonary TB & 18 & 15 & 83.3 \\
3. Subtotal TB & $\mathbf{8 1}$ & $\mathbf{6 9}$ & $\mathbf{8 5 . 2}$ \\
4. Pulmonary non-TB & 26 & 4 & 15.4 \\
5. Extrapulmonary non-TB & 64 & 12 & 18.8 \\
6. Subtotal non-TB & $\mathbf{9 0}$ & $\mathbf{1 6}$ & $\mathbf{1 7 . 8}$ \\
Overall total & $\mathbf{1 7 1}$ & $\mathbf{8 5}$ & $\mathbf{4 9 . 7}$ \\
\hline
\end{tabular}

$\mathrm{N}$, Total number of individuals; $\mathrm{n}$, number of individuals with periostitis.

$18.8 \%(12 / 64)$ of people with an extrapulmonary non-TB cause of death had new bone formation on the ribs.

The difference in frequency found between "cause of death" and the occurrence of new bone formation on the ribs is summarized in Table 2. The frequency of periosteal reaction varied significantly in all situations considered except between the pulmonary TB and nonpulmonary TB group of diseases (groups 1 and 2) and the pulmonary non-TB and extrapulmonary non-TB individuals (groups 4 and 5).

\section{DISCUSSION \\ Rib lesion frequency according to "cause of death" groups}

Pulmonary tuberculosis. From a total of 1,236 ribs from the 54 individuals with pulmonary TB as a cause of death and with observable ribs, $287(23.2 \%)$ had new bone formation, with $56 \%(158 / 282)$ affected on the left side and $44 \%(124 / 282)$ affected on the right. Although the left side was more affected than the right, this was not statistically significant $\left(\chi^{2}=67.061\right.$, df $\left.72, P>0.5\right)$. In pulmonary TB individuals, the number of ribs involved varied from 1-13, the most common number being three and seven ribs (10 individuals each), followed by two and four ribs (7 individuals). With respect to new bone formation on particular ribs, the 1st and 12 th ribs were affected with new bone formation in only one individual, respectively (both cases on the left side). Formation was also rare on the 11 th pair (only 5 individuals affected: 2 on the left, and 3 on the right side). More common locations were the 4th to 6th ribs (47), 4 th ribs (47), 5th ribs (47), and 6th ribs (42). Moreover, these lesions were very often more severe on ribs 4-6. Bone formation was mainly seen on the vertebral ends as a continuous "plaque" that could extend along the rib shaft. In those individuals who had died from pulmonary TB, the region of the rib most affected was the vertebral end $(69.5 \%)$, while the middle shaft and sternal ends had similar involvement (around 15\% of the cases).

There were 8 adults with bilateral pulmonary tuberculosis recorded as a cause of death. However, only 3 showed lesions on both sides of the rib cage: 2 were only affected on the left side, and 1 on the right side. For one individual, it was impossible to determine laterality due to rib fragmentation, and it can only be stated that five portions of ribs were affected. The eighth individual (sk. 86) presented "compact" lamellar bone, rather than woven bone. However, 21 individuals with pulmonary TB as a cause of death showed rib lesions on both sides of the thorax.
TABLE 2. Variation of occurrence of periosteal reaction on ribs between groups analyzed by chi-square test ${ }^{1}$

\begin{tabular}{lccc}
\hline & \multicolumn{3}{c}{ Ribs } \\
\cline { 2 - 4 } Group of diseases & $\chi^{2}$ & $\mathrm{df}$ & $P$ \\
\hline $1 / 2 / 3 / 4$ & 77.601 & 3 & $<0.0001$ \\
$3 / 4 / 5$ & 77.569 & 2 & $<0.0001$ \\
$1 / 2$ & 0.63 & 1 & $>0.5$ \\
$1 / 4$ & 40.104 & 1 & $<0.0001$ \\
$3 / 4$ & 44.234 & 1 & $<0.0001$ \\
$3 / 5$ & 63.998 & 1 & $<0.0001$ \\
$3 / 6$ & 77.486 & 1 & $<0.0001$ \\
$4 / 5$ & 0.143 & 1 & $>0.5$ \\
\hline
\end{tabular}

${ }^{1}$ For identification of disease groups (1-6), see Table 1 .

Extrapulmonary tuberculosis. Of the 18 individuals with nonpulmonary tuberculosis as a cause of death and observable ribs, $3(16.7 \%)$ did not show any periosteal reaction. They died from peritoneal TB with pleurisy and hepatitis (sk. 286) and tuberculosis (sk. 469); the third case had renal TB (sk. 375) and was admitted for kidney surgery and then autopsied. The remaining 15 $(83.3 \%)$ had rib lesions. Thirteen of these individuals also had respiratory system involvement listed in the cause-of-death data: 9 had pulmonary TB, 3 had tuberculous pleurisy, and 1 had "granúlia" TB. However, because this was associated with other diseases, they were classified in a different group from pulmonary TB. Only two individuals who had died from forms of TB that do not affect the thoracic region had rib lesions: these comprised a case of "tuberculosis" (sk. 455) and a person with mesenteric TB (sk. 32). However, both individuals had left and right ribs affected by new bone formation.

For this group, the number of ribs affected varied from $2-16$. Both sides of the rib cage were affected in 7 individuals, with unilateral rib involvement only seen in 4 cases each. As in the previous group, more common and more severe reactions occurred from the 4 th to 6 th ribs. In these 15 individuals, the 1 st and 12 th ribs were not involved in the pathological process.

Pulmonary nontuberculous. In the pulmonary nontuberculous cause-of-death group, only 4 individuals $(15.4 \%)$ had a periosteal reaction on the ribs (Table 1 ). One was a case of pulmonary aspergillosis (sk. 407) in a male individual, aged 31 , who was a commerce employee. He was hospitalized at the CUH and autopsied. Macroscopically, new bone formation was deposited from the 3rd to 10th right ribs as a thin layer of new bone along the shaft and at the vertebral end. This reaction of the periosteum is also visible on the radiograph (Fig. 1). The other 3 cases occurred in vaguely defined assigned causes of death: "purulent pleurisy" (sk. 308) was the illness recorded in a soldier aged 30, who died in the Military Hospital, and for the other two individuals who died at the $\mathrm{CUH}$, the cause of death recorded was "pulmonary gangrene:" a male individual aged 32 who was hospitalized for 5 days (sk. 489), and a female who died in hospital after 25 days at age 43 (sk. 88). The right ribs of this last individual had slight postmortem damage, while on her left ribs, the better state of preservation allowed the detection of new bone formation on her 3rd ribs in a pattern that could be confused with lesions found in individuals with pulmonary TB. The 4 th to 10 th ribs in transverse section presented a 

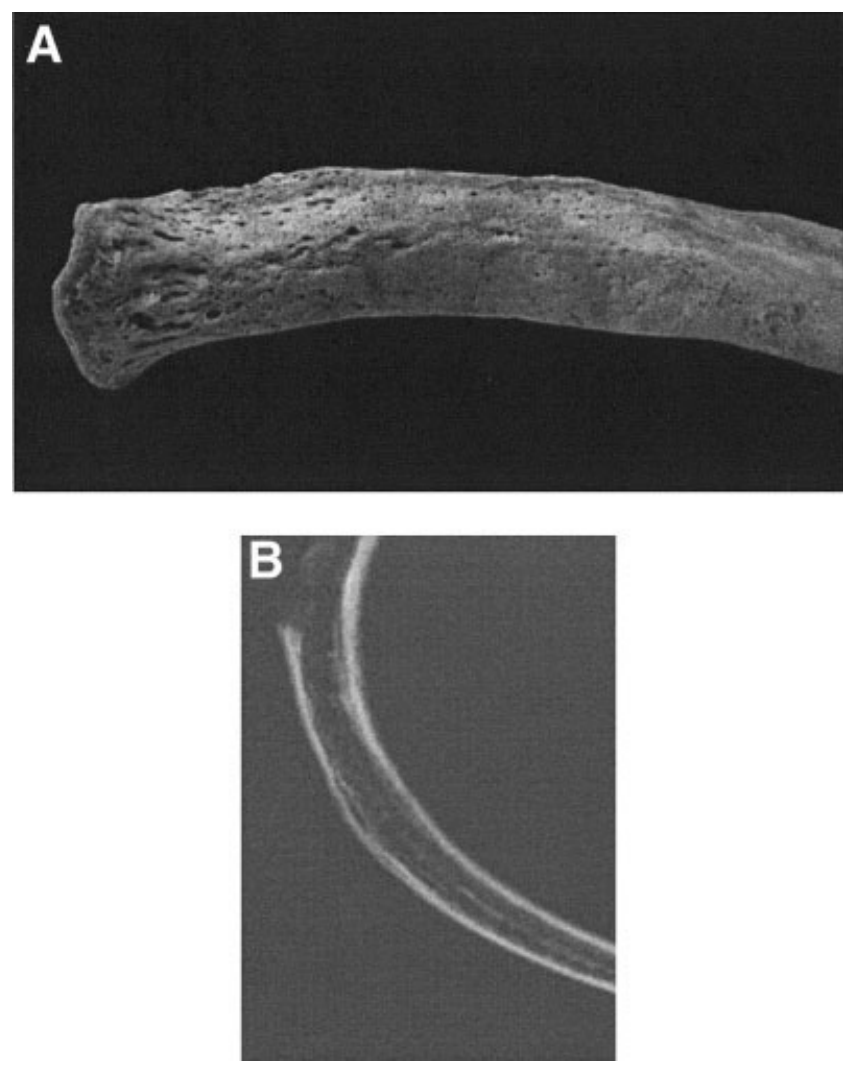

Fig. 1. Left rib with mixture of woven and lamellar bone at vertebral end (A) and slight layer of new bone along shaft, also visible in radiographic image (B) (senograph DMR, $30 \mathrm{kV}$, 30 mAseg) (sk. 407).

triangular shape. Radiographically, this layer of new bone on the visceral surface of the rib was very thin.

Extrapulmonary nontuberculous. For the fourth group identified by cause of death, $18.8 \%$ of individuals (12/64) showed rib lesions (Table 1). These included individuals who died from heart disease (4 cases), peritonitis ( 2 cases), brain hemorrhage (2 cases), and a tumor (?), accident, syphilis, and nephritis (1 case each). Two individuals with peritonitis as cause of death had their lower ribs affected. In individual 299, a male who died at age 22 , only the 10 th, 11 th, and 12 th left ribs had signs of infection along the shaft (Fig. 2), visible on a radiograph by increased density. The other individual (sk. 326), a female aged 27, showed extensive postmortem destruction; however, new bone formation occurred from the 1st to 5 th ribs at their sternal ends and from the 6th to 11th ribs both at the midshaft and vertebral ends. A female aged 42 years (sk. 254), who died at home due to endocarditis, showed periosteal reaction on 11 of her 23 existent ribs, despite destruction of parts of the ribs as a result of postmortem damage. The side more affected was the left (from the 1st to 9th ribs), and both the vertebral end and midshaft of the ribs presented new bone formation, also visible in radiographs (Fig. 3). On the right side of the thoracic cage, the 1st rib was missing, and periosteal reaction occurred at the vertebral end of the 2 nd and 3rd ribs.

CUH (Santos, 1999) and Instituto de Medicina Legal (IML) records revealed that individual 202 (male, aged

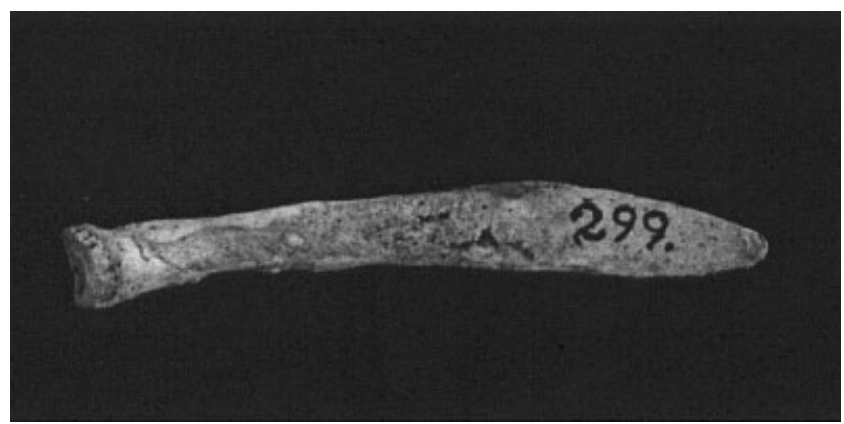

Fig. 2. Rib showing infectious process that affected visceral surface (sk. 299).
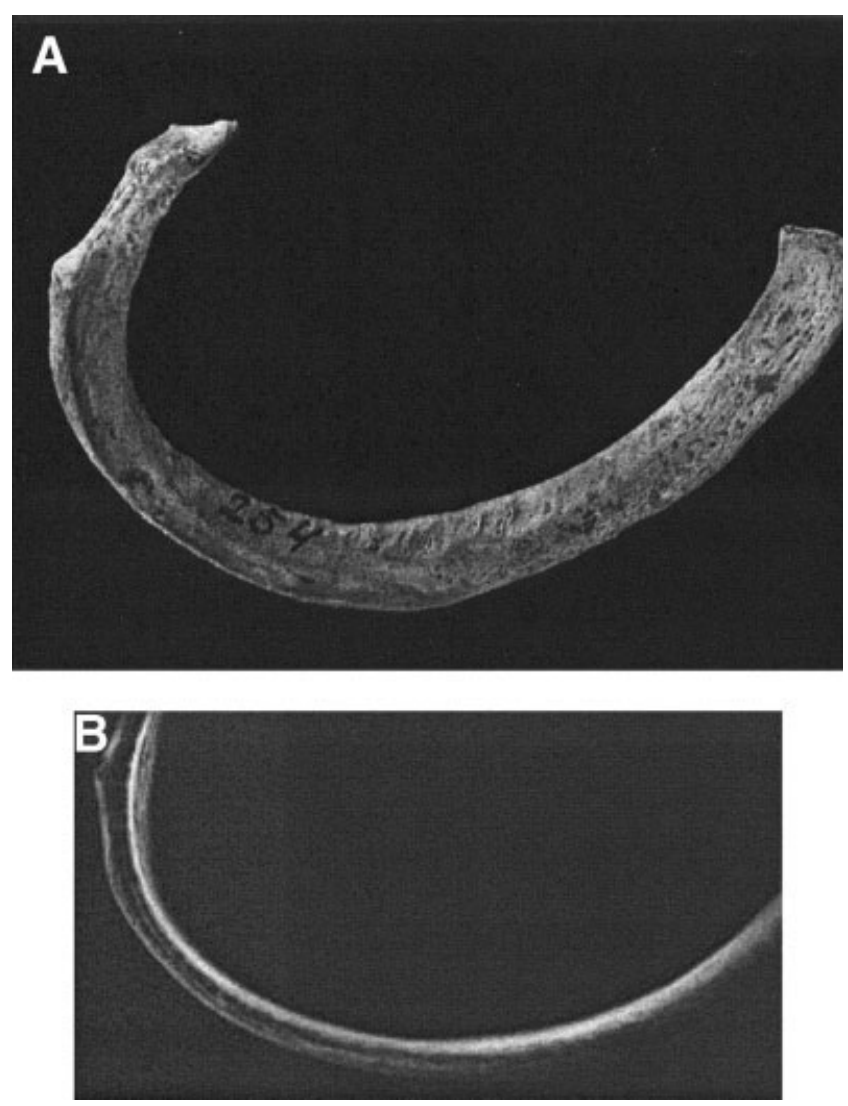

Fig. 3. View of a rib (A), showing rough texture of its visceral surface and periosteal reaction along the shaft, also visible (B) on a radiograph (senograph DMR $30 \mathrm{kV}, 30 \mathrm{mAseg}$ ) (sk. 254).

32) suffered an accident that led to a rupture and infection of the bladder. On the day of hospitalization, an urethrostomy was performed, and 44 days later, during autopsy, it was noted that the right pleural cavity contained around $100 \mathrm{~cm}^{3}$ of yellow liquid and a wound in the perineal region. The pelvic bones were broken, and four ribs showed new bone formation surrounding a traumatic lesion, as seen in Figure 4. A similar lesion occurred in the 8th left rib of an individual who died of subacute pulmonary TB (sk. 302); however, for that male, aged 40 years, accidental trauma was not mentioned. The last case in this group (sk. 384) had a destructive lesion located ca. $75 \mathrm{~mm}$ from the sternal extremity (Fig. 5) of 


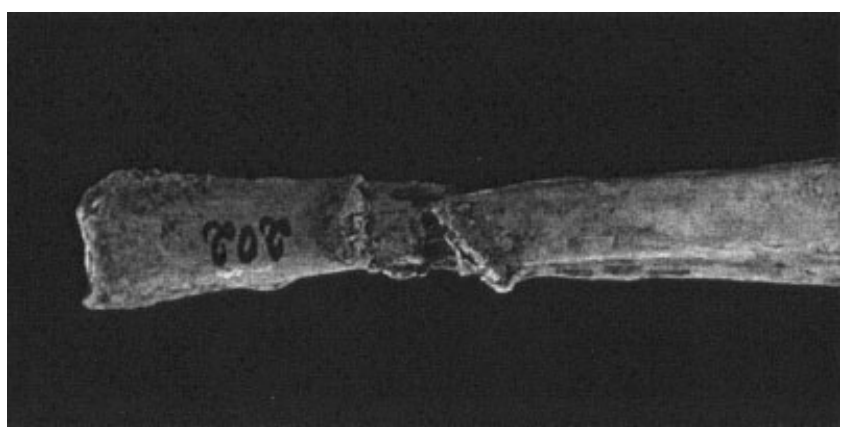

Fig. 4. Vertebral end of left rib, with layer of new bone covering traumatic lesion (sk. 202).

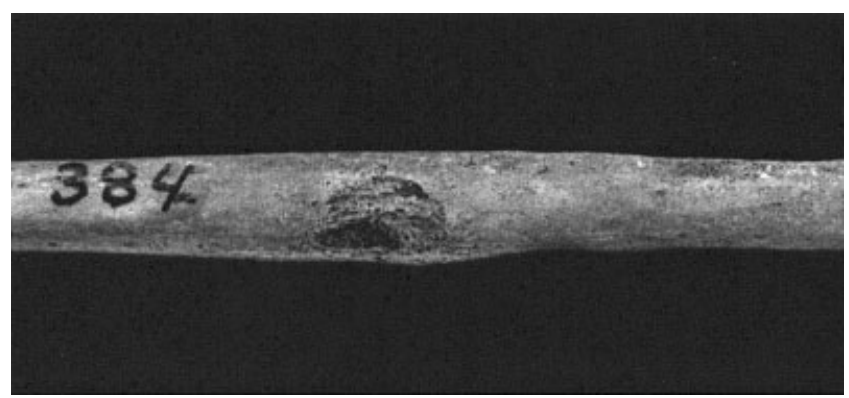

Fig. 5. Left rib with osteolytic lesion on visceral surface of its shaft (sk. 384).

one the left ribs (the ribs were fragmented, but it appeared to be the 8th). This 60-year-old industrialist died from "cephalic syphilis" and aortitis. Superior and anterior radiographs were taken, which revealed the localized destructive lesion surrounded by an increase of bone density due to new bone deposition.

\section{General discussion of the data}

There is general agreement among paleopathologists that the diagnosis of TB in human remains it is not easy. Thus, subjects such as the origin and evolution of TB, based on skeletal data, are still very controversial, due to the nonspecificity of some skeletal lesions (Crubézy et al., 1998). A diagnosis of TB made by paleopathologists relies mainly on Pott's disease of the spine, followed by changes in the hip and knee joints. However, the tubercle bacillus attacks bone much less frequently than soft tissue (Ritchie, 1952). Pulmonary TB is the more common form of this disease today, as it probably was in the past. Barata (2000), in a study of CMC records for the period 1910-1914, verified that $70 \%$ of tuberculous causes of death were of pulmonary TB. The analysis of the CUH "nosographic movement" (systematic description of diseases) revealed that pulmonary TB was the most frequent cause of hospitalization (49.1\%) and of death $(64.8 \%)$ from 1919-1936. Moreover, from a total of 3,165 cases of TB recorded at the CUH in the period 1919-1930, Pott's disease was responsible for 323 (10.2\%) admissions and $1.52 \%$ (7/460) of deaths; pulmonary TB represented $44.6 \%$ (1411 of 3,165 ) of admissions and $64.6 \%$ (297 of 460) of deaths (Universidade de Coimbra, 1919, 1934, 1935, 1936). Nonetheless, the medical literature does not necessarily describe all the diagnostic criteria that could be used for pulmonary TB identifica- tion which can be used in paleopathology. This disease can, of course, spread from the lungs to surrounding bone tissue, especially in cases of host resistance and a long incubation period, and if a person is not treated. Thus, the frequency rate of pulmonary TB is underestimated in recent historical contexts, and could be at least partially responsible for the large difference between rates of $\mathrm{TB}$ in past human skeletons and contemporary documentary sources.

\section{Differential diagnosis of rib lesions}

Pulmonary tuberculosis. In this study, new bone on ribs was significantly more common in individuals who had died from TB: $85.7 \%$ (54 in 63) of the people who died from pulmonary TB had a periosteal reaction on their ribs (Table 1). Table 3 compares the number of individuals affected by rib lesions in three other studies of 20th century documented skeletal collections. In those studies, the number of ribs affected per individual varied from $1-13$, but 3 or 7 ribs were affected most commonly. In the current study, the new bone occurred on both sides of the thoracic cage in 28 individuals, but unilaterally in 36 more individuals (22 on the left and 14 on the right side) (Table 4). The location of the periosteal reaction was more common at the head and neck regions, and the more severe lesions occurred on the 4th to 6th ribs.

Similar results were obtained for the juveniles of the CISC (Table 3) (Santos and Roberts, 2001). In the 11 juveniles who died from pulmonary TB, 10 had new bone formation on their ribs $(90.9 \%)$, and only 2 of the 48 who did not die from TB $(4.2 \%)$ had lesions. For those juveniles who died from pulmonary TB, new bone occurred from the 2 nd to 10 th ribs (Table 4). The number of ribs involved varied from $1-7$, with 4 being most common. In these cases, the left side was more affected than the right, but ribs from both sides were also affected in 4 individuals, and the 4 th to 6 th ribs were most involved. Bone formation was mainly seen on the vertebral ends (Table 4) and was woven in nature in the majority of cases (Santos and Roberts, 2001).

Earlier studies of the Hamann-Todd Collection revealed that new bone formation on ribs was more frequent in tuberculous individuals (Table 3), and of 352 individuals who died from pulmonary TB, 31 (8.8\%) had lesions on the visceral surfaces of the ribs (Kelley and Micozzi, 1984). In the Terry Collection, a stronger connection was found between pulmonary $\mathrm{TB}$ and rib lesions. Roberts et al. (1994) analyzed 1,718 individuals from the Terry Collection, and found that rib lesions were more common in individuals dying from pulmonary TB $(61.6 \%$, or 157 of 255$)$ than in individuals dying from a nontuberculous pulmonary cause of death $(22.2 \%$, or 51 of 230). The difference between the results in the three identified collections (Tables 3 and 4) may be the effect of the reliability of cause of death recorded. However, a person could have rib lesions as a result of TB, despite TB not being stated as cause of death (Roberts et al., 1994).

Notwithstanding the difficulty of comparing the exact location of new bone on the ribs, Table 4 displays the available data. Concerning laterality, both sides of the rib cage were usually affected in all skeletal collections, as is also the case in living people. Eyler et al. (1996) reported thickening of ribs on the side affected by TB in a study of chest radiographs. They considered antero- 
posterior views of 156 patients with a diagnosis of TB for 5 or more years $(\mathrm{N}=30)$, chronic pleural infections $(\mathrm{N}=$ $41)$, empyema $(\mathrm{N}=25)$, and as a control group, no pulmonary disease; 60 control subjects were also considered. In the ossuary (dated from the 15th century) investigated by Pfeiffer (1991), 136 left and 123 right ribs were affected, and only Kelley and Micozzi (1984) reported a predominance of involvement of the ribs of the left side by a ratio of approximately two to one. In individuals with pulmonary TB in the CISC (Table 4) apart from those individuals with bilateral lesions (32), ribs were more affected on the left side (26:16).

Eyler et al. (1996, p. 925) concluded that "the most common condition associated with rib enlargement was pulmonary TB." Despite these data linking new bone formation on ribs with pulmonary TB, researchers are still cautious about this possible additional diagnostic criterion for TB (e.g., Buikstra and Williams, 1991; Roberts and Buikstra, 2003), since no correspondence has been reported in living pulmonary tuberculous individuals. These criteria do not refer to subtle bone lesions frequently seen on ribs and other bones of the skeleton in archaeological populations. However, this could be a response to a primary infection that disseminated from the lung to the pleura and subsequently the visceral surface of the ribs (Roberts, 1999). Furthermore, TB on ribs is described in the clinical literature as bone destruction (Wassersug, 1941; Leader, 1950), and autopsies do not usually examine the visceral surfaces of ribs, even when pleural adhesions are present. Furthermore, rib observation is unnecessary for pulmonary TB diagnosis by physicians, despite potentially being important for diagnosis in paleopathology (Santos and Roberts, 2001).

The location of rib lesions in the thoracic cage seems to agree with the selective location of pulmonary TB in the apical and posterior segments of adult lungs, extending from the inferior portions of the superior lobes to the superior portions of the inferior lobes (Barata et al., 1987). Lung infection begins at a peripheral and subpleural site (Aufderheide and Rodríguez-Martín, 1998) in the middle and lower lungs (Hopewell, 1994). This selective location for adult pulmonary TB was described around 200 years ago by W. Stark and later confirmed by others (Barata et al., 1987). These areas correspond to the vertebral ends of the 3rd to 8 th ribs. Periosteal reaction was more frequent on the 4th and 8th ribs in both Kelley and Micozzi (1984) and Roberts et al. (1994). Pfeiffer (1991, p. 195) detected lesions from the 3rd to 10th ribs occurring on the vertebral ends "continuing anteriorly to varying degrees." Nevertheless, atypical locations can occur, as Barata et al. (1987) reported in their study of radiographs from pulmonary TB individuals ( $8 \%$, or $8 / 100)$.

Another finding was an increase in the thickness of ribs, identified as a morphological feature on radiographs. Enlargement of ribs on the affected side was also mentioned by Guttentag and Salwen (1999) and Eyler et al. (1996) in patients, especially with tuberculosis. In the CISC individuals, the more common location was at the vertebral end (Fig. 6), and in some cases, porosity was also visible. The most striking case was recorded in individual 403 (Fig. 7), whose ribs were around $14 \mathrm{~mm}$ thick. Radiographs were taken in a supero-inferior view which clearly showed that ca. $5 \mathrm{~mm}$ of their thickness resulted from new bone deposition. The conversion of new woven bone to lamellar bone occurred in ribs from several individuals. The exact extent of this modification was impossible to determine, since it would have necessi- 
TABLE 4. Distribution of new bone formation on ribs in tuberculous individuals (N) studied for each collection according to side and rib number affected, and location on rib ${ }^{1}$

\begin{tabular}{|c|c|c|c|c|c|c|}
\hline \multirow[b]{2}{*}{ Reference } & \multirow[b]{2}{*}{$\mathrm{N}$} & \multirow[b]{2}{*}{ Side } & \multirow[b]{2}{*}{ Rib number } & \multicolumn{3}{|c|}{ Location } \\
\hline & & & & Vertebral & Mid & Sternal \\
\hline $\begin{array}{l}\text { 1. Kelley and } \\
\text { Micozzi (1984) }\end{array}$ & 39 & Left $>$ right $(2: 1)$ & 4 th to 8 th & \multicolumn{3}{|c|}{ Exact location not specified } \\
\hline 2. Roberts et al. (1994) & 155 & Bilateral & Upper & More common & Present & Present \\
\hline $\begin{array}{l}\text { 3. Santos and } \\
\text { Roberts (2001) }\end{array}$ & $10^{2}$ & $\begin{array}{l}4 \text { both } \\
4 \text { left/2 right }\end{array}$ & $\begin{array}{l}\text { 2nd to 10th } \\
\text { More common } \\
\text { from 4th to } 6 \text { th }\end{array}$ & 40 & 10 & 5 \\
\hline 4. Current study & $64^{3}$ & $\begin{array}{l}28 \text { both } \\
22 \text { left/14 right }\end{array}$ & $\begin{array}{l}\text { 1st to } 12 \text { th } \\
\text { More common } \\
\text { from } 4 \text { th to } 6 \text { th }\end{array}$ & 275 & 61 & 63 \\
\hline
\end{tabular}

${ }^{1}$ 1, Hamman Todd Collection, Cleveland, Ohio; 2, Terry Collection, Washington, DC; 3, Coimbra Identified Skeletal Collection, Coimbra, Portugal (nonadults); 4, Coimbra Identified Skeletal Collection, Coimbra, Portugal (adults).

${ }^{2}$ Pulmonary tuberculosis.

${ }^{3}$ Pulmonary TB and other TB affecting lungs or pleura (two individuals were excluded because ribs were very fragmented).

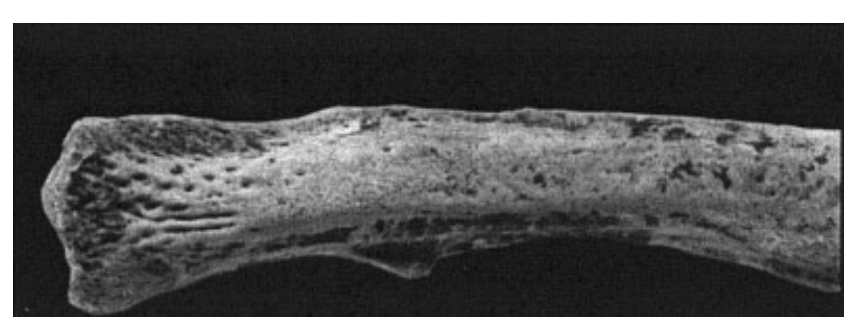

Fig. 6. Vertebral end of rib from individual 264.

tated radiographs of all studied ribs. The picture provided by periosteal changes is probably dependent on the phase of the disease (early, acute, chronic, recovering, healing, or healed), and age and immunity of the individual (Gladykowska-Rzeczcka, 1998). Chronic periostitis due to inflammatory disease may be evident on radiographs (Oxford University Press, 1998), but only recognizable radiographically when extracortical new bone has been formed (Chundun, 1991). Furthermore, Kelley and Micozzi (1984) stated that many subtle bone lesions, such as rib periostitis, are radiographically invisible to clinicians treating living people. As Ip et al. (1989, p. 243) noted in a patient, "the lack of clinical report of rib involvement in pleuropulmonary tuberculosis may be partly due to insensitivity of the chest roentgenogram in picking up early skeletal disease." Thus, the pattern of "skeletal involvement in orthopaedic diseases may not be well known" (Ortner, 1991, p. 8). Moreover, as shown in this study, subtle new bone formation was impossible to visualize on rib radiographs in the normal anatomical position for radiographs of the chest. Very thick layers of new bone on rib surfaces, however, may be seen as cortical thickening on a supero-inferior radiograph of the ribs. Analyses of rib lesions by scanning electron microscopy indicate an increase in "vascularity on the visceral surfaces on the ribs with active deposition of new bone around and over the vascular channels," and moreover, "in some cases, this may occur several times before the person's death" (Wakely et al., 1991). It is not surprising that subtle bone damage which may be associated with TB (especially in the lungs) is not described as a diagnostic criterion in the clinical literature, as it is probably not even recognized as present.

In the group of individuals with pulmonary TB as cause of death, the majority had a slight layer of new bone adherent to the internal face of the ribs. The exception was the individual (sk. 11) who also had lesions described as "coral-like" on all the ribs (Fig. 8), since they were very exuberant and different from previous descriptions. This type of lesion was present in all the thoracic and pelvic bones, and the proliferative features appear to resemble metastatic carcinoma (Ortner et al., 1991; Anderson et al., 1992). Thus, the lesions prevented identification of tuberculous lesions.

Extrapulmonary tuberculosis. In this group, 15 cases of periostitis were identified on the ribs (Table 3). Among them were cases of lung diseases such as pleural TB and pulmonary TB. Because pulmonary TB in these cases was associated with other diseases, they were not considered in the pulmonary TB group. In these skeletons, the 1st and 12th ribs did not show any periosteal reaction and, as in the previous group, the vertebral ends were the region of the rib shaft most affected.

Two individuals from the CISC died of peritoneal TB: a female aged 19 years (sk. 234) reported by Santos and Roberts (2001), and an adult (sk. 340) who also suffered from pulmonary TB; both skeletons showed rib lesions. However, some differences were found when comparing these changes with those resulting from pulmonary TB. The lower ribs were affected, and the more severe lesions were in this location; the middle of the shaft and/or sternal ends were also involved. Any intra-abdominal organ, as well as the peritoneum, can be involved in TB. Abdominal TB occurs equally in both sexes, and is more common in young adults and the elderly (Hopewell, 1994). However, intestinal and peritoneal TB are two very rare forms of abdominal TB ( $0.5 \%$ in some series), and are associated with mortality rates that reach $7 \%$ (Martins et al., 1994). Alvarez and McCabe (1984) found that peritoneal TB represented 11\% (8 out of 71) of cases of extrapulmonary tuberculosis. The pathogenesis of peritoneal TB is usually by hematogenous dissemination from other affected organs, mainly the lungs, by reinfection of a peritoneal latent focus, or by contamination from a ganglion (Araújo et al., 1988). Peritonitis can also be caused by a rupture of tuberculous lymph nodes within the abdomen: signs and symptoms are pain, often accompanied by abdominal swelling, fever, weight loss, and anorexia. Nevertheless, active pulmonary TB is rare in patients with tuberculous peritonitis (Hopewell, 1994). In some clinical cases, other organs such as the lungs 

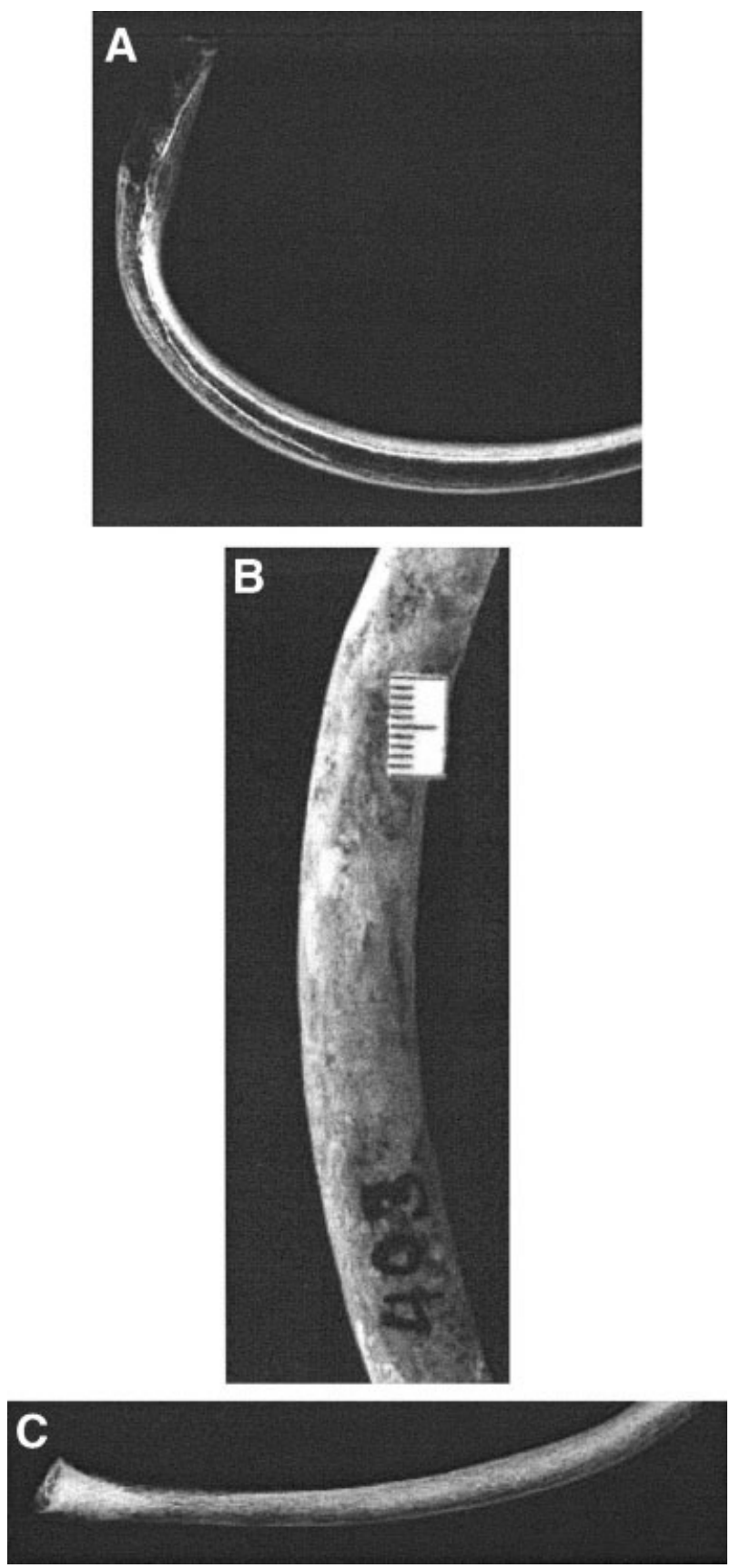

Fig. 7. Superior view of left rib of individual 403 (B) and its radiographic image in supero-inferior (A) and antero-posterior (C) views (senograph DMR, $30 \mathrm{KV}, 45 \mathrm{mAseg}$ ).

are not involved, and thus peritoneal TB is caused by hematogenous dissemination (Martins et al., 1994).

A different condition is seen in empyema TB, a variety of pleural TB (Argo Editora, 1957; Roberts et al., 1994); it is much less common than tuberculous-induced pleurisy. It usually results from a rupture of a "parenchymal focus via a bronchopleural fistula" (Johnston et al., 1973). A female aged 24 who died in hospital (sk. 300) had "empyema TB" on the right side "and pulmonary TB" documented as her cause of death. The left ribs from the 5 th to 9 th had, at their vertebral ends, a layer of new bone, more severe on the 7 th, while on the right side, the

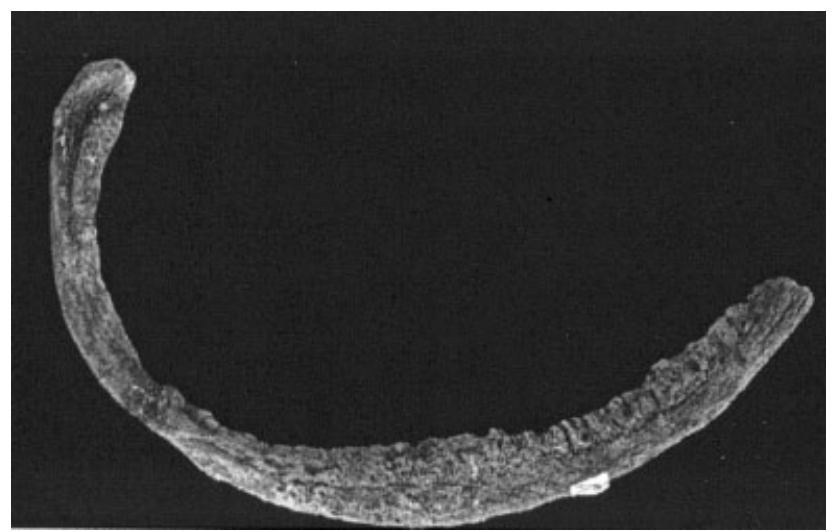

Fig. 8. Superior view of 9th right rib with "coral-like" new bone formation (sk. 11).

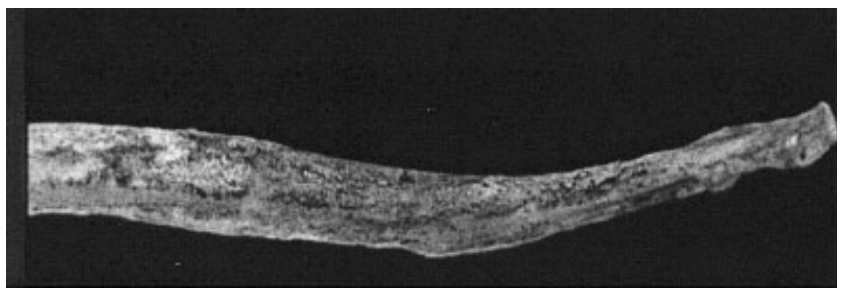

Fig. 9. Right rib with signs of infection along shaft caused by tuberculous empyema (sk. 300), clearly showing texture of new bone.

infection had spread over the internal face of all shafts of the 11 existent ribs, and showed a different texture when compared to ribs from cases of pulmonary TB (Fig. 9).

The remaining 3 individuals with rib lesions recorded were as follows: mesenteric TB (sk. 32), "tuberculosis" (sk. 455), and "granúlia" TB (sk. 251). This last term is equivalent to acute miliary TB or "disseminated TB" (Almeida, 1923; Argo Editora, 1957), and occurs when host defenses fail, either in a recently acquired or latent infection (Hopewell, 1994). In these individuals, the vertebral ends of the ribs were affected, and bilaterally in individuals 32 and 455 . The presence of rib lesions in a case of miliary TB is not surprising, because this type of TB frequently results from the spread of pulmonary TB as a result of "erosion of a parenchyma focus of tuberculosis into the blood or lymph vessels which may result in dissemination of the organism and a 'miliary' pattern on the chest film" (Hopewell, 1994, p. 30). Thus, this is an acute form of TB, while pulmonary TB is essentially a chronic disease that may cause death due to hemoptysis (Rocha, 1890); this occurs when a branch of the pulmonary artery is severed (Aufderheide and Rodríguez-Martín, 1998). Autopsies of miliary tuberculous victims show that the organs most frequently involved are the liver, lungs, bone marrow, kidneys, adrenal glands, and spleen (Hopewell, 1994).

Pulmonary nontuberculous. Of 26 individuals (Table 3 ), only $4(15.4 \%)$ had new bone formation on the ribs. A male aged 31 (sk. 407), hospitalized for around 5 months, suffered from pulmonary aspergillosis and had involvement of the right vertebral ends of the right ribs, from the 3rd to the 10th; radiologically, a thin layer of new bone covering the middle shaft region was observed (Fig. 
1). According to the Argo Editora (1957), this disease is caused by fungi, and its manifestations are similar to pulmonary TB. For individual 308, who died from purulent pleurisy at the Military Hospital, it was impossible to collect further information. Lesions affected the vertebral end of the 9th right rib, and both the vertebral and sternal ends of the 4th to 11th left ribs, being more severe on the 9 th. This ambigu- ous cause of death may implicate a diagnosis of TB.

The last two cases died from pulmonary gangrene: individual 489 was 32 years old, and had a 5-day stay at the CUH in the "male tuberculous ward;" his right ribs from the 6 th to the 10th had periostitis at their vertebral ends. Individual 88 was 43 years old at death, and was hospitalized for 25 days. Her ribs had a triangular cross section, and macroscopically, this was visible on the 3rd left rib as a slight layer of new bone at the vertebral and sternal ends; a radiograph showed a very thin dense area of bone along the shaft. Porto (1934) considered pulmonary gangrene to be the cause, leading to a subacute or chronic nontuberculous pulmonary suppuration, with recurrence and necrosis of the pulmonary tissue.

Extrapulmonary nontuberculous. Finally, within this group of 64 adult individuals, $12(18.8 \%)$ had lesions in their observable ribs (Table 3). A male aged 32 (sk. 202) was hospitalized for 44 days at the CUH due to an accident. In his autopsy report, among other information, it was stated that he was "slim, $52 \mathrm{~kg}$ in weight, with anaemia" ("emagrecido e anemiado"), "the right lung had $280 \mathrm{~g}$, nothing relevant to be registered, the left with $400 \mathrm{~g}$ weight showed pleural adhesions difficult to destroy at the level of the superior lobe" ("apresentava aderências à pleura parietal, difíceis de desfazer ao nível do lobo superior"). It is stated that as the consequence of all the injuries, "septicemia arose," ("deu lugar a septicemia"), and he had "lesions of pleurisy adhesive at the left side" ("lesões de pleuresia adesiva à esquerda"). In fact, he had new bone formation on four left middle ribs, localized around what seemed to be a traumatic lesion (Fig. 4).

Heart disease was the cause of death for 4 individuals with new bone formation on the ribs: 3 died at home, and individual 487 was a male aged 27 years at death, who was a sailor ("marítimo") without residence, who came from France to the CUH. He was hospitalized from September 1933-September 1934 due to heart insufficiency. In his file was written, "It is recommended that this patient receive nutrition from outside the hospital because (he) has lost his appetite due to the long period of internment" "Convêm que este doente receba alguma alimentação de fora visto estar com pouco apetite em virtude de estar internado desde há muito"). These data are associated with a long period of hospitalization, which encouraged speculations about the possibility that he had contracted tuberculosis. A woman aged 46 years at death (sk. 175) had periostitis present at the vertebral ends of two left ribs. She died at the CUH after 52 days of hospitalization. However, her cause of death was not definitively stated, and her file mentioned "stomach cancer (?)." Another female aged 34 years at death (sk. 304) died at home from acute nephritis, and slight new bone formation was present on the vertebral end of her 7 th right rib. There were also 2 cases, a male (sk. 297) and female (sk. 311), respectively, 32 and 39 years old at time of death. Both died at home from brain hemorrhage, and both had periostitis on their ribs. In one individual (sk. 297), the periosteum of the ribs was damaged postmortem. Thus, only the 9 th left rib showed new bone at the midshaft and sternal regions, while in sk. 311, these changes were present in the 3rd to 10th left ribs, and on the mid and sternal ends of the shafts. On the right side, only the 9th rib was affected at its vertebral end. However, doubts exist about the accuracy of records, as discussed above; perhaps the disease stated as the cause of death was not the only contributory cause of death.

Two other individuals with new bone formation on their ribs died from peritonitis: individual 299, a male aged 22 years at death, died at the Military Hospital suffering from "peri-nephritis with pus and generalized peritonitis." The texture of the rib lesions (Fig. 2) was quite different from previous descriptions, occurring at the vertebral end of the 10th left and extending along the shafts of the 11 th and 12 th ribs. New bone was present on the visceral surface of the left innominate. Encystment peritonitis ("peritonite enquistada") was the cause of death recorded for a female aged 28 years (sk. 326) who died at the CUH after 43 days of hospitalization. In her patient file was written, "patient in bad general state" ("doente em mau estado geral"), and despite the postmortem damage, on the right side of the rib cage new bone was visible on the sternal end of the 2 nd to 6 th ribs, and on the vertebral end of the 7 th to the 11th.

Lastly, there were two cases of syphilis, one in a male aged 29 years (sk. 199) who died after almost 8 months of hospitalization from an aortic aneurysm, also suffering from syphilis ("coexistent disease"). The ribs, from the 3rd to the 10th, had periostitis at their sternal ends, and on the 9th, the vertebral end was also affected. The other individual (sk. 384) was 60 years old at time of death and died at home due to "cerebral syphilis" and aortitis. At the sternal end of a left rib (probably the 8th) there was a destructive lesion (Fig. 5) on the visceral surface. Its radiological appearance agrees with one of the three types of rib lesion caused by TB, described by Leader (1950, p. 359) as a "cyst-like lesion entirely within the rib."

Tuberculosis of the ribs, and other flat bones, is probably a consequence of their marrow-forming structure and could be initiated by $M$. tuberculosis or $M$. bovis (Aufderheide and Rodríguez-Martín, 1998). Rib involvement in tuberculosis may take place by hematogenous spread from a distant focus or by direct expansion from an adjacent soft-tissue or bone lesion (Ip et al., 1989). However, there is no agreement about frequency rates of involvement. While most authors report it as rare in living patients (Rechtman, 1929; Leader, 1950; Johnson and Rothstein, 1952; Sinoff and Segal, 1975; Asnis, 1997; Chang et al., 1999) or uncommon (Leader, 1950; Brown, 1980), others say it is more common (Wassersug, 1941; Tatelman and Drouillard, 1953). Described as a destructive lesion in clinical data, such involvement was previously reported as a single and isolated lesion (Wassersug, 1941; Asnis, 1997), but subsequent studies found other TB lesions in these cases (Tatelman and Drouillard, 1953). The middle ribs are more often affected, and secondary involvement of adjacent ribs can occur (Konschegg, 1934; Chang et al., 1999). The shaft is the most frequently affected site of infection (Tatelman and Drouillard, 1953). In living patients, Wassersug (1941) noted that the right side was slightly more affected than the left, and this was more common in young adults, namely males. Apart from TB, other possible diagnoses are chronic nonspecific osteomyelitis, treponemal disease, and tumors of the chest wall (Was- 
sersug, 1941; Tatelman and Drouillard, 1953; Fitzgerald and Hutchinson, 1992; Chang et al., 1999; Ortner, 2003). A lesion comparable to the one described for individual 384 from the CISC was recorded in a young female, studied as a forensic case in the US, from which was identified DNA from Mycobacterium tuberculosis (Donoghue et al., 1999; Ubelaker et al., 2000). Mays et al. (2001) reported lytic lesions on the vertebral ends of ribs attributed to extensions of vertebral foci of tuberculous infection in archaeologically derived individuals with a positive identification of DNA from Mycobacterium tuberculosis.

\section{CONCLUSIONS}

Paleopathological studies take as their starting point clinical data on how particular diseases affect the human body, and specifically the skeleton. However, there are many bone lesions observed during paleopathological examinations that do not readily correspond to modern disease profiles developed for clinical medical practice (Ortner, 1991; Santos and Roberts, 2001). Research into "paleotuberculosis" enables us to understand the effect of this disease upon human mortality and morbidity worldwide throughout the millennia, and it can also possibly assist in efforts to eliminate, or at least control, this disease in the future (Santos, 2000).

Assuming that the causes of death for the CISC were correct, and that the lesions observed in the tuberculous individuals were caused by TB, for these individuals who died before antibiotics were developed for treatment, macroscopic lesions related to TB largely exceed published figures in the paleopathological literature. The trends reported were valid for the adults of this population, and also for juvenile individuals (Santos and Roberts, 2001). New bone formation on ribs was significantly more common in individuals who died from TB. Although not pathognomonic, this lesion on the visceral surface of the ribs seems to suggest pulmonary tuberculosis as a differential diagnosis. In addition, the type of bone formed and the location of lesions may allow for the differential diagnosis of peritonitis, or neoplastic or pulmonary (non-TB) diseases.

In summary, research into rib involvement in TB needs more work in certain areas. Previous data seem to suggest that pathological features in ribs could be caused by several diseases. In the case of new bone formation on ribs, it was suggested that it is due to an inflammatory process in the lung tissue spreading to the visceral surface of the ribs (Roberts et al., 1998). However, in the current study, it appears that these differential diagnoses could be made:

- In cases of pulmonary TB, ribs in the middle of the rib cage are those most affected by a layer of new bone and mainly at the vertebral ends of the ribs.

- Among individuals with peritonitis, the periosteal reaction is more severe, and is seen in the lower ribs. Moreover, when pus is present, the layer of new bone is thicker, clearly showing the infective process. Thus, the lower location on the rib cage may be a clue for distinguishing between pulmonary TB and peritonitis.

- Extensive infection along the rib shaft was also visible in the middle of the right side of the rib cage in the individual who died from "empyema TB on the right side and pulmonary TB," while in the left ribs, the tex- ture of the new bone was identical to that found in cases of pulmonary TB.

- Supero-inferior radiographs must be taken of thickened ribs to verify the existence, or not, of a layer of old remodeled periosteal new bone.

- The neoplastic lesions on the ribs in individual 11 may be differentiated from the pulmonary TB cases, because the former are exuberant with a "coral-like" form.

Taking these factors into account, a diagnosis of possible cases of TB in the past may increase. In particular, the most common form of TB (i.e., pulmonary TB) may induce rib changes. As Guttentag and Salwen (1999) pointed out from patient observation, the ribs may be important for diagnosing disease. However, the application of these criteria in the differential diagnosis of rib lesions to past populations will always have limitations. In archaeologically derived skeletons, ribs are often fragmented, which may obscure their identification (Roberts et al., 1998). Even in individuals from the CISC, inhumed for only short periods of time, the periosteal layer was not completely preserved in all cases, and the periosteal plaques easily became detached. Thus, the presence of periosteal new bone may even have been underestimated in this study. In archaeological material, taphonomic factors could be expected to hinder the observation of these subtle, but important, lesions in identifying possible cases of tuberculosis in the past (Santos, 2000). In addition, the results could be unrepeatable because the exact definition of the areas of the rib may suffer from interobserver error; sometimes it may be difficult to decide the exact location of the new bone formation (e.g., between midshaft and the sternal end). Moreover, sometimes it is also very difficult to determine presence or absence, namely when darkcolored ribs are present.

The recommendations that arise from this study are that all ribs and/or rib fragments from a population should be observed for periosteal reaction, with location in the rib cage, area of rib involved, and the nature of bone formed recorded. From this investigation, it appears that these changes may be relevant to a diagnosis of pulmonary TB. In addition, care must be taken in the interpretation of the nature and distribution of new bone formed on ribs, as the characteristics of these lesions seem to be pertinent to specific disease processes. The application of standard data recording allows comparisons between different documented collections, and archaeological sites, and provides more accurate diagnosis of thoracic and abdominal diseases, namely pulmonary and gastrointestinal TB. Confirmation of the trends noted in this study is needed in other identified skeletal collections and clinical studies.

\section{ACKNOWLEDGMENTS}

The authors thank the Anthropological Museum at the University of Coimbra for the opportunity to study the Coimbra Identified Skeletal Collection, and also Coimbra University Hospital for the radiographs and the Instituto de Medicina Legal (Coimbra). A.L.S. thanks Mary Lucas Powell. This work developed from a presentation at the 70th Annual Meeting of the American Association of Physical Anthropologists (Kansas City, MO) in 2001 (grant from Fundação Luso-Americana). 


\section{LITERATURE CITED}

Almeida AR. 1995. A tuberculose. Doença do passado, do presente e do futuro. Porto: Fundação Bial.

Almeida T. 1923. Formas tifóides da tuberculose pulmonar. A Med Modern 10:321-325.

Alvarez S, McCabe W. 1984. Extrapulmonary tuberculosis revisited: a review of experience at Boston City and other hospitals. Medicine (Baltimore) 63:25-55.

Anderson T, Wakely J, Carter A. 1992. Medieval example of metastatic carcinoma: a dry bone, radiological, and SEM study. Am J Phys Anthropol 89:309-323.

Araújo F, Pinto F, Sousa G. 1988. Tuberculose peritoneal. Jorn Med 125:79-81.

Argo Editora. 1957. Dicionário Enciclopédico de Medicina. Adaptação Portuguesa. Lisboa: Argo Editora.

Asnis DS. 1997. Tuberculosis of the rib. Clin Infect Dis 24:10181019.

Aufderheide A, Rodríguez-Martín C. 1998. The Cambridge encyclopedia of human paleopathology. Cambridge: Cambridge University Press.

Baker B. 1999. Early manifestations of tuberculosis in the skeleton. In: Pálfi G, Dutour O, Deák J, Hutás I, editors. Tuberculosis: past and present. Budapest-Szeged: Golden Book/ Tuberculosis Foundation. p 301-307.

Barata CJ. 2000. Estudo paleodemográfico no Cemitério da Conchada 1910-1914 [seminar report]. Coimbra: Universidade de Coimbra.

Barata F, Arrobas A, Pato R. 1987. Radiologia da tuberculose pulmonar do adulto. Revisão de 100 casos. Jorn Med 123:247-249.

Bennike P. 1999. Facts or myths? A re-evaluation of cases of diagnosed tuberculosis in the past in Denmark. In: Pálfi G, Dutour O, Deák J, Hutás I, editors. Tuberculosis: past and present. Budapest-Szeged: Golden Book/Tuberculosis Foundation. p 511-219.

Boylston A. 1991. Addingham (ACH90). Human skeletal report. Bradford: Calvin Wells Laboratory, University of Bradford.

Brock TD. 1982. The etiology of tuberculosis by Robert Koch (translation from 1882). Rev Infect Dis 4:1270-1274.

Brown TS. 1980. Tuberculosis of the ribs. Clin Radiol 31:681-684.

Buikstra JE, Williams S. 1991. Tuberculosis in the Americas: current perspectives. In: Ortner DJ, Aufderheide AC, editors. Human paleopathology: current syntheses and future options. Washington, DC: Smithsonian Institution Press. p 161-172.

Canci A, Minozzi S, Borgonini-Tarli S. 1996. New evidence of tuberculous spondylitis from Neolithic Liguria (Italy). Int J Osteoarch 6:497-501.

Chang JH, Kim SK, Lee WY. 1999. Diagnostic issues in tuberculosis of the ribs with a review of 12 surgically proven cases. Respirology 4:249-253.

Chundun Z. 1991. The significance of rib lesions in individuals from a Chichester medieval hospital. M.Sc. Bradford: University of Bradford.

Crubézy E, Ludes B, Poveda J-D, Clayton J, Crouau-Roy B, Montagnon D. 1998. Identification of Mycobacterium DNA in an Egyptian Pott's disease of 5,400 years ago. C R Acad Sci [III] 321:941-951.

Cule J. 1999. Medical history of tuberculosis. In: Pálfi G, Dutour O, Deák J, Hutás I, editors. Tuberculosis: past and present. Budapest-Szeged: Golden Book/Tuberculosis Foundation. p 31-37.

Daniel T, Bates J, Downes K. 1994. History of tuberculosis. In: Bloom B, editor. Tuberculosis: pathogenesis, and control. Washington, DC: ASM Press. p 13-24.

Donoghue H, Ubelaker D, Spigelman M. 1999. The use of paleomicrobiological techniques in a current forensic case. In: Pálfi G, Dutour O, Deák J, Hutás I, editors. Tuberculosis: past and present. Budapest-Szeged: Golden Book/Tuberculosis Foundation. p 363-368.

Earnest M, Sbarbaro J. 1993. A plague returns. Sciences: 14-19.

El-Najjar M. 1981. Skeletal changes in tuberculosis: the Hamann-Todd Collection. In: Buikstra J, editor. Prehistoric tuberculosis in the Americas. Chicago: Northwestern University Archeological Program. p 85-97.
El-Najjar M, Al-Shiyab A, Al-Sarie I. 1997. Cases of tuberculosis at 'Ain Ghazal, Jordan. Paleorient 22:123-128.

Eyler W, Monsein L, Beute G, Tilley B, Schultz L, Schmitt W. 1996. Rib enlargement in patients with chronic pleural disease. Am J Radiol 167:921-926.

Fitzgerald R, Hutchinson C. 1992. Tuberculosis of the ribscomputed tomographic findings. Br J Radiol 65:822-824.

Formicola V, Milanesi Q, Scarsini C. 1987. Evidence of spinal tuberculosis at the beginning of the fourth millenium BC from Arene Candide Cave (Liguria, Italy). Am J Phys Anthropol 72:1-6.

French R. 1993. Scrofula (scrophula). In: Kiple K, editor. The Cambridge world history of human disease. Cambridge: Cambridge University Press. p 998-1000.

Garten AMA. 1997. Skeletal evidence for tuberculosis and treponematosis in a Late Fort Ancient skeletal population from Kentucky. Ph.D. dissertation, University of Kentucky.

Gladykowska-Rzeczycka J. 1998. Periostitis: cause, form and frequency in paleopathology. Mankind Q 38:217-236.

Goggel S. 1992. Biological anthropology skeletal report 1. M.Sc. dissertation on osteology, palaeopathology and funerary archaeology. Sheffield: University of Sheffield.

Guttentag AR, Salwen JK. 1999. Keep your eyes on the ribs: the spectrum of normal variants and diseases that involve the ribs. Radiographics 19:1125-1142.

Hopewell P. 1994. Overview of clinical tuberculosis. In: Bloom $\mathrm{B}$, editor. Tuberculosis: pathogenesis, protection, and control. Washington, DC: ASM Press. p 25-46.

Ip M, Chen N-K, So Shun-Yang, Chiu S-W, Lam W-K. 1989. Unsual rib destruction in pleuropulmonary tuberculosis. Chest 95:242-244.

Jankauskas R. 1999. Tuberculosis in Lithuania: palaeopathological and historical correlations. In: Pálfi G, Dutour O, Deák J, Hutás I, editors. Tuberculosis: past and present. BudapestSzeged: Golden Book/Tuberculosis Foundation. p 551-559.

Johnson M, Rothstein E. 1952. Tuberculosis of the rib. J Bone Joint Surg [Am] 34:878.

Johnston TM, McCann W, Davey WH 1973. Tuberculosis bronchopleural fistula. Am Rev Respir Dis 107:30-41.

Kelley M, El-Najjar M. 1980. Natural variation and differential diagnosis of skeletal changes in tuberculosis. Am J Phys Anthropol 52:153-167.

Kelley M, Micozzi M. 1984. Rib lesions in chronic pulmonary tuberculosis. Am J Phys Anthropol 65:381-386.

Kelley M, Murphy S, Levesque D, Sledzik P. 1994. Respiratory disease among protohistoric and early historic Plains Indians. In: Owsley DW, Jantz RL, editors. Skeletal biology in the Great Plains. Migration, warfare, health, and subsistence. Washington, DC: Smithsonian Institution Press. p 123-130.

Konschegg J. 1934. Die Tuberkulose der Knochen. Handb Speziell Pathol Anat Histol 9:377-437.

Lambert PM. 2002. Rib lesions in a prehistoric Puebloan sample from southwestern Colorado. Am J Phys Anthropol 117:281-292. Leader SA 1950. Tuberculosis of the ribs. AJR 63:354-359.

Lopes C, Santos AL, Cunha E. 1999. A possible case of human tuberculosis on a medieval farm in Corroios (Portugal) [abstract]. In: Cockburn E, editor. Paleopathology Association. Papers on paleopathology presented at the 26th Annual Meeting of the Paleopathology Association, Columbus, Ohio. Detroit: Paleopathology Association. p 12.

Magyar L. 1999. The history of the term "tuberculosis". In: Pálfi G, Dutour O, Deák J, Hutás I, editors. Tuberculosis: past and present. Budapest-Szeged: Golden Book/Tuberculosis Foundation. p 23-27.

Mann R. 1993. A method for siding and sequencing human ribs. J Forensic Sci 38:151-155.

Marques C. 2000. Um visitante da Idade Média: estudo antropológico de um esqueleto proveniente de Pinhel [report]. Coimbra: Universidade de Coimbra.

Martins Y, Leitão J, Sá A, Nascimento Costa JM, Carvalho A, Pinto A, Severo F, Almiro E, Porto A. 1994. Peritonite tuberculosa-a propósito de dois casos clínicos. Coimbra Med 15:347-352.

Mays S, Taylor GM, Legge AJ, Young, DB, Turner-Walker G. 2001. Paleopathological and biomolecular study of tuberculosis 
in a medieval skeletal collection from England. Am J Phys Anthropol 114:298-311.

Mays S, Fysh E, Taylor GM. 2002. Investigation of the link between visceral surface rib lesions and tuberculosis in a medieval skeletal series from England using ancient DNA. Am J Phys Anthropol 119:27-36.

Molnár E, Marcsik A. 2003. Paleopathological evaluation of Hungarian skeletal remains from the 7th-9th centuries $\mathrm{AD}$. Antropol Port 19:85-99.

Molto J. 1990. Differential diagnosis of rib lesions: a case study from Middle Woodland Southern Ontario circa 230 AD. Am J Phys Anthropol 83:439-447.

Murphy E. 1994. An examination of human remains from Solar, County Antrim. M.Sc. Sheffield: University of Sheffield.

Ortner DJ. 1991. Theoretical and methodological issues in paleopathology. In: Ortner DJ, Aufderheide AC, editors. Human paleopathology. Current syntheses and future options. Washington, DC: Smithsonian Institution Press. p 5-11.

Ortner DJ. 2003. Identification of pathological conditions in human skeletal remains. San Diego: Academic Press.

Ortner D, Manchester K, Lee F. 1991. Metastatic carcinoma in a leper skeleton from a medieval cemetery in Chichester, England. Int J Osteoarch 1:91-98.

Oxford University Press. 1998. Concise colour medical dictionary. Oxford: Oxford University Press.

Pfeiffer S. 1991. Rib lesions and New World tuberculosis. Int J Osteoarch 1:191-198.

Porter R. 1996. Medical science. In: Porter R, editor. The Cambridge illustrated history of medicine. Cambridge: Cambridge University Press. p 154-201.

Porto J. 1934. Notas clínicas sôbre supurações pulmonares. Coimbra Med 1:300-303.

Powell ML. 1988. Status and health in prehistory. A case study of the Moundville chiefdom. Washington, DC: Smithsonian Institution Press.

Powell ML. 1991. Endemic treponematosis and tuberculosis in the prehistoric southeastern United States: biological costs of chronic endemic disease. In: Ortner DJ, Aufderheide AC, editors. Human paleopathology. Current syntheses and future options. Washington, DC: Smithsonian Institution Press. p 173-180.

Rechtman AM. 1929. Tuberculous osteitis with pathologic resection of seventh rib. J Bone Joint Surg 11:557-559.

Regan M, Irish J, Turner C. 1993. Another possible case of skeletal tuberculosis in prehistoric Arizona, AD 1150-1450. Am J Phys Anthropol [Suppl] 16:163-164 [abstract].

Ritchie W. 1952. Paleopathological evidence suggesting preColumbian tuberculosis in New York State. Am J Phys Anthropol 10:305-317.

Roberts CA. 1999. Rib lesions and tuberculosis: the current state of play. In: Pálfi G, Dutour O, Deák J, Hutás I, editors. Tuberculosis: past and present. Budapest-Szeged: Golden Book/Tuberculosis Foundation. p 311-316.

Roberts CA. 2003. Tuberculosis in Britain: its history and palaeoepidemiology. Antropol Port 19:101-119.

Roberts CA, Buikstra JE. 2003. The bioarchaeology of tuberculosis: a global view on a reemerging disease. Gainesville: University Press of Florida.

Roberts CA, Cox M. 2003. Health and disease in Britain: from prehistory to the present day. Gloucestershire: Sutton Publishing, Ltd.

Roberts CA, Lucy D, Manchester K. 1994. Inflammatory lesions of ribs: an analysis of the Terry Collection. Am J Phys Anthropol 95:169-182.

Roberts CA, Boylston A, Buckley L, Chamberlain A, Murphy EM. 1998. Rib lesions and tuberculosis: the palaeopathological evidence. Tubercle Lung Dis 79:55-60.

Rocha A. 1890. Clínica interna. As tuberculoses intra-thoracicas hemorrhagicas. Coimbra Med 10:229-232.

Rocha MA. 1995. Les collections ostéologiques humaines identifiées du Musée Anthropologique de l'Université de Coimbra. Antropol Port 13:7-38.

Sager P, Schalimtzek M, Møller-Christensen V. 1972. A case of spondylitis tuberculosa in the Danish Neolithic age. Dan Med Bull 19:176-180.

Santos AL. 1999. TB files: new hospital data (1910-1936) on the
Coimbra Identified Skeletal Collection. In: Pálfi G, Dutour O, Deák J, Hutás I, editors. Tuberculosis: past and present. Budapest-Szeged: Golden Book/Tuberculosis Foundation. p 127-134.

Santos AL. 2000. A skeletal picture of tuberculosis. Macroscopic, radiological, biomolecular, and historical evidence from the Coimbra Identified Skeletal Collection. Ph.D. dissertation on biological anthropology. Coimbra: Universidade de Coimbra.

Santos AL, Cunha E. 1997. Some paleopathological aspects from the medieval necropolis of Granja dos Serrões (Portugal). In: López, MM, Sánchez J, editors. La enfermedad en los restos humanos arqueológicos. Cádiz: Universidade de Cádiz-Servicio de Publicaciones. p 335-339 and erratum.

Santos AL, Roberts C. 2001. A picture of tuberculosis in young Portuguese people in the earlier 20th century: a multidisciplinary study of the skeletal and historical evidence. Am J Phys Anthropol 115:38-49.

Sinoff C, Segal I. 1975. Tuberculous osteomyelitis of the rib: a case report. S Afr Med J May:865-866.

Sledzik P, Bellantoni N. 1994. Brief communication: bioarchaeological and biocultural evidence for the New England vampire folk belief. Am J Phys Anthropol 94:269-274.

Souza SM. 2002. Rib periosteal reactions in skeletons from Atacama, Chile: tuberculosis. In: Departamento de Antropologia da Universidade de Coimbra, editors. 14th European Meeting of the Paleopathology Association: program-abstracts. Coimbra: Departmento de Anthropologia. p 156.

Stodder ALW. 1990. Paleoepidemiology of Eastern and Western Pueblo communities in protohistoric New Mexico. Ph.D. dissertation, University of Colorado.

Stodder ALW. 1996. Paleoepidemiology of Easter and Western Pueblo communities in protohistoric and early historic New Mexico. In: Baker BJ, Kealhofer L, editors. Bioarcheology of Native American adaptation in the Spanish Borderlands. Gainesville, FL: University Press of Florida. p 148-176.

Tatelman M, Drouillard E. 1953. Tuberculosis of the ribs. AJR 70:923.

Ubelaker DH, Jones EB, Donoghue HD, Spigelman M. 2000. Skeletal and molecular evidence for tuberculosis in a forensic case. Anthropologie 38:193-2000.

Universidade de Coimbra. 1919. Boletin dos Hospitais da Universidade de Coimbra. Volume II. Coimbra: Universidade de Coimbra.

Universidade de Coimbra. 1934. Boletin dos Hospitais da Universidade de Coimbra. Volume IV. Coimbra: Universidade de Coimbra.

Universidade de Coimbra. 1935. Boletin dos Hospitais da Universidade de Coimbra. Volume V. Coimbra: Universidade de Coimbra.

Vale AA. 1936. A robustez da criança rural em idade escolar. Coimbra: Coimbra Editora, Lda.

Vincent V, Perez MG. 1999. The agent of tuberculosis. In: Pálfi G, Dutour O, Deák J, Hutás I, editors. Tuberculosis: past and present. Budapest-Szeged: Golden Book/Tuberculosis Foundation. p 139-145.

Wakely J, Manchester K, Roberts C. 1991. Scanning electron microscopic of rib lesions. Int J Osteoarch 1:185-189.

Waldron T. 1987. The relative survival of the human skeleton: implications for palaeopathology. In: Boddington A, Garland A, Janaway R, editors. Death, decay and reconstruction. Approaches to archaeology and forensic science. Manchester: Manchester University Press. p 55-64.

Wassersug J. 1941. Tuberculosis of ribs. Am Rev Tuberculosis 44:716-721.

Weiss D, Møller-Christensen V. 1971. An unusual case of tuberculosis in a medieval leper. Dan Med Bull 18:11-14.

Wiltschke-Schrotta K, Berner M. 1999. Distribution of tuberculosis in the skeletal material of eastern Austrian sites. In: Pálfi G, Dutour O, Deák J, Hutás I, editors. Tuberculosis: past and present. Budapest-Szeged: Golden Book/Tuberculosis Foundation. p 543-550.

Wood JW, Milner G, Harpending HC, Weiss KM. 1992. The osteological paradox. Problems of inferring health from skeletal samples. Curr Anthropol 33:343-379. 